РОЛЬ КОНЦЕРТМЕЙСТЕРА-БАЯНІСТА (АКОРДЕОНІСТА) НА ЗАНЯТТІ 3 НАРОДНОГО ТАНЦЮ В ЗАКЛАДАХ ВИЩОЇ ОСВІТИ

\title{
THE ROLE OF BAYAN (ACCORDION) ACCOMPANISTAT THE FOLK DANCE CLASS IN HIGHER EDUCATIONAL ESTABLISHMENTS
}

Статтю присвячено виявленню особливос-
тей діяльності концертмейстера-баяніста
(акордеоніста) на занятті з народного
танцю в закладах вищої освіти. Розглянуто
сприятливі педагогічні умови для форму-
вання та розвитку знань, умінь і навичок у
студентів-хореографів. Визначені структурні елементи компетентності концертмейстера-баяніста (акордеоніста). До загальних компетентностей відносять: уміння враховувати вікові й індивідуальні особливості студентів-хореограсрів, знання психології та педагогіки, музики, навички взаємодії з людьми, когнітивну гнучкість, розвинутий емоційний інтелект. До вузькоспеціальних компетентностей ми віднесли: професійне володіння музичними інструментами, читання нот з листа, підбір мелодії й акомпанементу (із фрранцузького - «супроводжувати» сольну партію, вокал, танець, пісню), навички транспозиції, аранжування, гри в ансамблі, знання елементів вокалу, хореографрії, дивергент ної вправності, уміння відтворити мелодіі народного танцю і вміння бачити рухи танцюристів, вести за собою хореографрічний колектив, уміти підбирати вступ, програш та кінцівку музичного твору. Але найголовніше під час уроку з народного танцю - че правильно підібраний музикальний супровід та створення сприятливої психологічної атмоссрери для розвитку відповідних навичок у студентів-хореографрів.

Під час заняття з народного танцю концертмейстер-баяніст повинен правильно підібрати мелодію, знати танцювальні рухи, уміти вправно відтворювати музику. Необхідно також брати до уваги артистичні та фрізичні здібності студентів-хореографрів. Особливо че важливо тоді, коли ту саму вправу або сольні трюки виконують по одному. У такому разі потрібно узгодити темп хореограсрічного виконання з музичним супроводом. Звукова насиченість партії повинна відрізнятись, але вони радше будуть тонкі, майже непомітні від оптимального темпу.

Концертмейстер-баяніст (акордеоніст) повинен розуміти, що він не $\epsilon$ головним музичним виконавцем, він співпрацює в ансамблі зі студентами-хореографрами, тим самим допомагає глибше проникнути в емоційну структуру народного танцю.

Ключові слова: концертмейстер, баяніст (акордеоніст), творчість, активізація, хореографрія, хореографр, народний танець, заняття, музика.

The article reveals the peculiarities of the work of bayan (accordion) accompanist at the folk dance class in higher educational establishments. Favorable pedagogical environment that improves the knowledge and skills of studentschoreographers is researched in the article.

The structural elements of the competence of bayan (accordion) accompanist are defined. General competence features include: the ability to contemplate the age and personal pecu liarities of students-choreographers, the knowledge of psychology, pedagogics and music, the skills in communication with people, cognitive flexibility, well-developed emotional intellect. Specialized field of expertise includes the ability to masterly play musical instruments, read the notes, select the melodies for accompaniment (from French "to accompany" the solo version, vocals, dancing, song), the skills in transposition, arrangement, play in ensemble, know the elements of vocals, choreography, divergent expertness, the capacity to reproduce the melodies of the folk dance and see the dancers' movements, lead the dance group, select the intro, interlude and outro of the musical work. However at the folk dance class, the most important skill is to select the right musical accompaniment and create a positive psychological environment to help the students-choreographers develop the necessary skills.

At the folk dance class, the bayan accompanist needs to select the suitable melody, know the dance movements, and skillfully reproduce the music. It is important to take into consideration the artistic and physical abilities of the studentschoreographers. This is especially important when the same exercises or solo stunts are performed by the dancers alternately. In this case, the tempo of the dance performance and the musical accompaniment need to be harmonized. The sound richness must differ, however it will more likely be fine and almost obscure, considering the best-fitting tempo.

Bayan (accordion) accompanist must understand, that he is the main and leading musical performer, who cooperates with the studentschoreographers, and this way helps them fully comprehend the emotional structure of the folk dance.

Key words: accompanist, bayan (accordeon) player, creativity, activization, choreography, choreographer, folk dance, class, music.

«Луцький педагогічний коледж»

Волинської обласної ради

Постановка проблеми в загальному вигляді. Робота концертмейстера-баяніста (акордеоніста) полягає в підборі й освоєнні музичного матеріалу, пов'язаного $з$ народним танцем, його хореографрічної специфікою, а також із віковими й індивідуальними особливостями студентів.

Освоєння музичної специфріки народної хореографрії можливо тільки за умови паралельного вивчення хореографічного мистецтва як класичного, так і народного танцю, розуміння їхніх спільних та відмінних рис.

Роль концертмейстера-баяніста (акордеоніста) $€$ малодослідженою в руслі наукових сентенцій, це спонукає нас до актуальної розвідки означеного індивідуума як учасника навчального-виховного процесу.

Аналіз останніх досліджень і публікацій. Обрана нами проблема майже не була предметом 
науково-методичних студій. Серед науковців, які розкрили особливості концертмейстерської діяльності, такі: Н. Воропаєв [4], Д. Комарницький [6], В. Лозова [8], С. Скворцова [12] й інші. Дослідники розглядали методичні аспекти роботи читання 3 листа і транспонування, сорормулювали корисні рекомендації концертмейстерамбаяністам (акордеоністам).

Питання щодо вдосконалення вмінь учителів музичних спеціальностей вивчали Л. Хоружа, М. Братко, О. Котенко, О. Мельниченко.

Виділення не вирішених раніше частин загальної проблеми. Вагомими $€$ дослідження постаті концертмейстера-баяніста (акордеоніста) у працях П. Андрійчука [1], А. Берези [2], О. Матковського [9], Т. Панасюк [10]; методичний посібник А. Душного орієнтовано на всебічний розвиток студентів-хореографів [5]. Однак робіт, спрямованих на аналіз сучасної ролі концертмейстера-баяніста (акордеоніста) на занятті з народного танцю в закладах вищої освіти, украй мало.

Мета статті - на основі наукової літератури з'ясувати особливості діяльності концертмейстера-баяніста (акордеоніста) під час занять із народного танцю в закладах вищої освіти.

Виклад основного матеріалу. Досить важливим $€$ музичний супровід танцю під час занять, але найголовніше - правильний підбір музики, яка буде максимально зручною для виконання рухів студентів-хореографрів.

Тому для ефективної співпраці студентів-хореограсрів та концертмейстера-баяніста (акордеоніста) останньому необхідно мати низку компетентностей.

Під поняттям «компетенція» ми розуміємо сукупність взаємозалежних якостей особистості (знання, уміння, навички, способи діяльності), необхідних для якісної продуктивної діяльності [7, c. 37].

Компетентність визначаємо як володіння відповідними компетенціями. Аналіз визначень педагогічної компетентності дає змогу стверджувати, що педагогічна компетентність є системою наукових знань, інтелектуальних і практичних умінь і навичок, особистісних якостей і утворень, яка за належної мотивації та високого рівня професійності психічних процесів забезпечує самореалізацію, самозбереження та самовдосконалення особистості педагога у процесі профресійної діяльності [12, с. 153].

Важливою умовою фрахової компетентності концертмейстера-баяніста є досконале володіння музичним інструментом.

В. Бурзанова переконана в тому, що розвиток профресійної компетентності зумовлюється особливостями багаторівневої, поліструктурної та багатовимірної музично-виконавської діяльності, пов'язаної із процесом художнього сприйняття, пізнання, осмислення й індивідуально-творчої інтерпретації музичного твору. Тому в освітньому процесі для розвитку професійної компетентності музиканта-інструменталіста необхідно використовувати спеціальні методи. Зокрема:

- на етапі сприймання музичного твору доцільно уявити музичний матеріал у синтезі звукового та візуального рядів. Це дозволить задіяти слуховий та зоровий аналізатори людини, збільшити об'єм отриманої інфрормації і відповідно активізувати дії перцептивно-рефлексивних механізмів, диореренціювати музично-слухові уявлення, розширити емоційно-образну сореру, доповнити банк музично-слуховою інфрормацією, тобто забезпечити розвиток музично-слухової компетентності. Адже музично-слухову компетентність характеризує розвиток емоційної сфери виконавця, його емоційну реакцію, міру емпатійного проникнення в художній образ;

- на етапі вивчення музичного твору доцільно застосовувати комплексний аналіз музичних творів на основі інтеграції історико-гуманітарних, музично-теоретичних і спеціальних знань (відбір музичного матеріалу і способів його вивчення) залежно від музичного твору. У процесі комплексного аналізу фрормується система художньоестетичних цінностей, поповнюється банк музичних знань, активізується раціонально-логічне мислення, дослідницькі навички, підвищується культура вербального спілкування, тобто розвивається музично-граматична компетентність.

Детальний аналіз нотного тексту наближає виконавця до інтерпретації, адекватної композиторському задуму. Знання й розуміння музичного тексту значною мірою обмежують виконавця і водночас допускають досить високий рівень інтерпретаційної свободи [3, с. 62-63].

На думку Т. Пляченко, організація та зміст роботи з фрормування профресійної компетентності у сорері інструментального виконавства мають бути спрямовані на те, щоб у професійній діяльності виявлялися такі компетентності:

- програмово-репертуарні (знання інструментального репертуару та здатність самостійно добирати інструментальні твори; уміння робити історико-стильовий, художньо-педагогічний, музично-теоретичний і технічно-виконавський аналіз інструментальних творів);

- технічно-виконавські (сформованість техніки гри на інструменті й індивідуальної виконавської манери - виконавська постановка; координація фрункцій рук та раціональність рухів; вправність пальців; володіння аплікатурними прийомами; штрихова техніка та звуковедення, культура звука; метроритмічна чіткість; сорормованість аналітикослухових навичок; доцільне використання технічних можливостей музичного інструмента; здатність до самоаналізу і самокоригування); 
- інтерпретаційні (здатність до виконавської інтерпретації музичних творів - дотримання авторського задуму композитора, стилю, жанру, форми твору; спроможність розкрити художній образ твору за допомогою виконавської техніки та виражальних засобів - динаміки, агогіки, логічного фрразування, тембрової відповідності тощо);

- інструментально-методичні (володіння методикою навчання гри на музичному інструменті);

- концертмейстерські (здатність до концертмейстерської діяльності);

- сценічні (готовність до культурно-освітньої та концертно-виконавської діяльності - здатність до психоемоційного саморегулювання та навіювання у процесі власного публічного виступу; сорормованість сценічної культури; артистизм; творчий імідж тощо) [11, с. 147-148].

Важливим у майстерності концертмейстерабаяніста (акордеоніста) є вміння читати ноти з листа. Правильно інтерпретувати текст та вдало його відтворювати можна за допомогою розвинених рівнів психологічного відображення. Перший рівень - сенсорно-перцептивний, полягає у зоровому прийнятті нот, які запам'ятовуються та зберігаються у вигляді уявлень. Другий рівень - зображувальний, тобто в особистості добре розвинені різні види уявлення: зорові, слухові, моторні. Третій рівень - розумовий, на даному етапі відбувається створення цілісного музичного образу.

Присутність концертмейстера під час навчальних занять впливає на розвиток у студентів-хореографрів різноманітних умінь, серед яких уміння виконувати рухи відповідно до ритму, динаміки, характеру твору. Для оформлення танцювальних занять використовуються невеликі за об'ємом музичні твори чи фрагменти з них. Варто зазначити, що дуже складно знайти народні твори, які цілком відповідають рухам вправ.

Технологія підбору концертмейстером музичного матеріалу для оорормлення уроку з хореографії здебільшого базується на системно-хореографрічних знаннях: основ хореографрії та сценічного руху, хореографрічній термінології, традиційних форм та етапів навчання в хореографії, фрорм побудови занять, обов'язкових імпровізаційних елементів, історії виникнення та розвитку шкіл і напрямів танцювального мистецтва.

Головні критерії підбору матеріалу для супроводу уроків, на думку Т. Панасюк, такі: яскраво виражена танцювальність, композиційна стрункість, періодичність, переважно квадратна структура, гомофонний склад, мелодійність, ясний метро-ритмічний малюнок [10, с. 45].

Отже, послідовне вивчення основних рухів народного танцю фрормує у свідомості концертмейстера-баяніста певні ритмо-артикуляційні фрормули, що є співзвучними і відповідними даному елементу танцю. Це допомагає підбору музичних уривків за їхніми фрактурними особливостями, що відповідають: темпу, фрормі, метро-ритму, характеру даного руху.

Роль концертмейстера-баяніста (акордеоніста) полягає в ознайомленні студентів-хореографів 3 історією та національною культурою народу через правильно підібрану музику.

Концертмейстер-баяніст (акордеоніст) повинен володіти інструментом, уміти образно охоплювати фрорму музичного твору, мати добру виконавську підготовку та розвинену музичну уяву. Не менш важливі набуті навички музичної майстерності.

На думку О. Матковського, роль концертмейстера-баяніста (акордеоніста) полягає в заохоченні до виконання рухів студентів-хореограсрів із народного танцю. Науковець уважає, що основні пріоритети концертмейстера-баяніста (акордеоніста) під час уроку такі:

- уміння правильно читати 3 листа баянної партії та використовувати її відповідно до власних виконавських можливостей, зважати водночас на можливості інструментів та композиторські складові частини;

- уміння підбирати мелодії й акомпанемент на слух, імпровізувати. Тобто грати відомі та прості у виконанні стилізації без підготовки чи, навпаки, підбирати гармонію до обраної теми;

- для роботи з вокалістами та хоровими колективами концертмейстер-баяніст (акордеоніст) повинен володіти вміннями використовувати транспозицію;

- для використання гри різнопланових клавірів та у процесі творчої гри на інструменті, коли перекладає епізоди зі збереженням основної тематичної лінії, концертмейстер-баяніст (акордеоніст) повинен володіти вміннями інструментувати й аранжувати;

- знати основні диригентські жести і прийоми;

- володіти навичками гри в ансамблі;

- знати основи вокалу, постановки дихання, артикуляції, голосу;

- знати основи хореографії та сценічного руху, основні рухи класичного, бального та народного танців [9, с. 211].

Отже, можна наголосити на тому, що роль концертмейстера-баяніста (акордеоніста) на заняттях 3 народного танцю полягає в умінні одночасно відтворювати мелодію і бачити рухи студентів-хореографрів, підбирати вступ, програш, кінцівку фррази, які необхідні в навчальному процесі. Мотивувати студентів-хореографів до навчання.

Під час підготовки до уроку концертмейстербаяніст (акордеоніст) підбирає народну музику, що відповідає не тільки ритму даного руху, але й його характеру. На уроці народного танцю ритм характеризує ті чи інші особливості національного або стилістичного порядку. Ритм кожного національного танцю має свої особливості, відтінки та нюанси, мета баяніста (акордеоніста) - донести ці ритмічні особливості, добиватись точного їх виконання. 
Концертмейстер-баяніст (акордеоніст) під час уроку стежить за діяльністю студентів-хореографрів, за ритмом і поготів. Рухи повинні виконуватись у строгому й точному порядку, студенти мають вчитись давати цілий ряд вистукувань, де трапляються малі дрібні рухи (ноти), синкопічні акценти та плескання.

Тому роль концертмейстера-баяніста (акордеоніста) у хореографічному творі дуже велика, вона проявляється у високохудожньому, гнучкому, музичному офрормленні уроку та розвитку уваги до внутрішнього розуміння музики студентів-хореограсрів. Неувага до розкриття музики в навчальному процесі породжує «затиск» у внутрішніх і зовнішніх, тобто перенапругу, скованість, без подолання яких не може бути свободи творчості. Звільнення від перенапруги може закінчитись успішно тільки за допомогою організованої уваги як внутрішньої, так і зовнішньої. Про внутрішню увагу говорилось у зв'язку зі слуханням та розумінням музики, про зовнішню, або фрізичну, увагу варто говорити, пов'язуючи ії 3 танцювальним або тренувальним завданням чи рухом. Не менш важливе вміння урізноманітнювати супровід уроку цікавою музикою.

А. Береза наголошує на тому, що під час праці над розвитком ритму не можна забувати про головне: про характерні та стилістичні особливості того чи іншого руху, про його внутрішнє забарвлення [2, с. 21].

П. Андрійчук уважає, що вміння правильно відчувати та вільно відображати інтонацію музики в танці так само необхідне, як правильне почуття ритму та розуміння теми. Можна вміти ритмічно танцювати, тонко та правильно сприймати зміст музичної теми, але не вміти відобразити її інтонації у своїх діях або танцях $[1$, с. 3].

Танець - це душа народу, виконавцю народних танців необхідно власне до нього ставлення, яскраве емоційне вираження [6, с. 14].

Специфріка виконання народних танців передбачає великий різновид динаміки і характеру виконання, ритмічних побудов, їхніх особливостей, техніки звукоутворення, знань і специфіки звучання, характерних для тієї чи іншої народності. Також багато народних танців потребують надто гарного володіння виконавською технікою і віртуозною грою.

Спілкування концертмейстера зі студентами через музику не тільки збагачує їхній внутрішній світ почуттями, думками, але й прилучає до мистецьких цінностей, спонукає до естетичних і духовних прагнень, фрормує їхнє світосприйняття.

Тому для навчальних цілей під час уроку з народного танцю найкращою є емоційно-образна, танцювально-дієва, оптимістична, вольова музика, з ясно та блискуче вираженим національним колоритом. Народна мелодія, оброблена для сценічного танцю, повинна відповідати лексиці народних сценічних рухів та малюнків танцю. Отже, народна музика повинна відповідати народному танцю.

Вивчення народного танцю, зі своїми особливостями в характері, ритмі і манері виконання, дає студентам-хореографам можливість напрацювати потрібну техніку виконання, збагатити творчу фантазію, розвинути координацію рухів, музикальність і відчуття ритму, проявити свій акторський темперамент, органічно відчувати себе на сцені.

Отже, музичні мелодії повинні бути простими, доступними та виразними, емоційними, такими, що підвищують працездатність і настрій. Використання народного пісенно-танцювального матеріалу поступово ускладнюється, збагачується й урізноманітнюється голосоведенням, малюнком гармонії, динамічними відтінками, прискоренням темпу. Під час розучування нової вправи необхідно пояснювати, у якому музичному розмірі виконується дана вправа, на яку частку такту припадає акцент вправи, відповідність темпу і характеру вправи та музики. На початку навчання народного танцю, коли засвоюються елементи основних рухів екзерсису, треба звернути особливу увагу на граматичні та синтаксичні навички в музиці.

А. Душний наголошує на тому, що незнання музично-хореографрічних основ створює недопустимий стилістичний різнобій, відображає серйозні наслідки безграмотності постановок етнографічного танцю, породжує еклектику понять хореографії. Це дискредитує чудову ідею розвитку народних танців і повинно викорінюватись на самому початку. Побудова етюдів і танців на народні теми вимагає добору народної музики, а не використання балетної музики композиторів [5, с. 92].

Сучасне хореографрічне мистецтво з його високою музичною культурою ставить перед концертмейстерам-баяністом (акордеоністом) високі професійні вимоги, передусім необхідна наявність у музиканта великого багажу знань і навичок досконалого володіння інструментом, а також розуміння природи й особливостей хореографрії.

Висновки. Отже, професійна діяльність концертмейстера-баяніста (акордеоніста) полягає передусім у створенні сприятливої психологічної атмосфрери для навчання студентів-хореографрів. На заняттях із народного танцю студенти-хореографи ознайомлюються 3 музичними творами, музичними фррагментами, можливістю послухати й емоційно відгукнутися на вираженні почуття. Народний танець розвиває у студентів сприйняття музичного супроводу в поєднанні з рухами, уміння вправно відтворювати рухи залежно від характеру музики, відчувати музичний настрій. Тому під час занять із народного танцю студенти-хореографи прагнуть розвивати вміння і навички виконувати завдання відповідно до характеру, темпу ритмічного малюнку музичного фррагмента, розвивати самостійну творчу активність, автоматизувати виконання завдань. 


\section{БІБЛІОГРАФІЧНИЙ СПИСОК:}

1. Андрійчук П. До питання розвитку концертмейстерських навичок у баяністів. Актуальні напрями відродження та розвитку народно-інструментального мистецтва в Україні : матеріали Всеукраїнської науково-практичної конференції, м. Київ, 24-31 березня 1995 р. Київ, 1995. С. 3-4.

2. Береза А., Нестерович Б. Концертмейстерський клас (баян, акордеон) : навчальна програма та методичні матеріали для студентів музично-педагогічних фракультетів із спеціальності 7.020207 «Музична педагогіка та виховання». Вінниця, 2006. 64 с.

3. Бурзанова В. Профресійна компетентність музиканта-інструменталіста: зміст, структура, методи розвитку. Наукові записки Бердянського державного педагогічного університету. 2014. Вип. 1. С. 61-67.

4. Воропаєва Н. Формування професійних і психолого-педагогічних якостей музиканта-концертмейстера. Актуальні питання мистецької освіти та виховання : збірник матеріалів Науково-практичної конференції викладачів і студентів кафедри вокально-хорової підготовки, теорії та методики музичної освіти, м. Вінниця, ВДПУ ім. Михайла Коцюбинського, 5 квітня 2018 р. Вінниця, 2018. С. 6-9.

5. Душний А. Методика активізації творчої діяльності майбутніх учителів музики у процесі музичноінструментальної підготовки : навчальний посібник для студентів вищих навчальних закладів. Дрогобич : Посвіт, 2008. 120 с.

6. Комарницький Д. Робота концертмейстерабаяніста на уроках народного танцю : навчальний посібник. Кам'янець-Подільський, 2017. 47 с.

7. Компетенції викладачів вищої школи в добу змін: діагностика та аналітика (за результатами дослідження в Київському університеті імені Бориса Грінченка) / Л. Хоружа та ін. Київ : Київський ун-т імені Бориса Грінченка, 2018. 92 с.

8. Лозова В. Формування педагогічної компетентності викладачів вищих навчальних закладів освіти. Педагогічна підготовка вищих навчальних закладів : матеріли Міжвузівської науково-практичної конфреренції. Харків : ОВС, 2002. 164 с.

9. Матковський О. Особливості роботи концертмейстера-баяніста в хореографічному класі (заняття 3 народного танцю). Світогляд - Філософрія - Релігія : збірник наукових праць ДВНЗ «Українська академія банківської справи Національного банку України» та Інституту фрілософрії ім. Г. Сковороди НАН України. Суми : ТОВ ВПП «Фабрика друку», 2014. Вип. 6. С. 211-216.

10.Панасюк Т. Змістовий компонент концертмейстерської діяльності. Актуальні питання мистецької освіти та виховання : збірник матеріалів Науково-практичної конференції викладачів і студентів кафедри вокально-хорової підготовки, теорії та методики музичної освіти, м. Вінниця, ВДПУ ім. Михайла Коцюбинського, 5 квітня 2018 р. Вінниця, 2018. С. 44-48.

11. Пляченко Т. Формування фахових компетентностей майбутнього вчителя музичного мистецтва на заняттях 3 музично-інструментальних дисциплін. Науковий часопис Національного педагогічного університету імені М.П. Драгоманова. Серія 14 : Теорія і методика мистецької освіти. 2015. Вип. 18. С. $146-150$.

12. Скворцова С. Види професійної компетентності вчителя. Наука і освіта. 2009. № 10. C. 153-156. 